\section{Questión}

Periodismo / Comunicación ISSN 1669-6581
- Av. $44 \mathrm{~N}^{\circ} 676,1^{\circ}$ piso

CP 1900 - La Plata - Argentina

( www.perio.unlp.edu.ar/question

Costa Rica: la Pandemia en el Caribe

Julio César Piedra Castillo

https://doi.org/10.24215/16696581e391

\title{
Costa Rica: la Pandemia en el Caribe
}

\section{Costa Rica: The Pandemic in the Caribbean}

\author{
Julio Cesar Piedra Castillo \\ Edad, 51 años, actualmente jubilado. \\ Labore 32 años como profesor técnico en la especialidad de Mecánica de Precisión. \\ Vivo en la Lucha de Desamparados, aproximadamente a 35 kilómetros de la capital San Jose. \\ NO TRABAJO PARA NINGÚN MEDIO. \\ juliopiedra40@gmail.com
}

\section{Enlace}

https://ar.ivoox.com/es/51717896 